\title{
Diet-tissue isotopic fractionation of the Pacific oyster Crassostrea gigas
}

\author{
H. Yokoyama*, Y. Ishihi, S. Yamamoto \\ National Research Institute of Aquaculture, Fisheries Research Agency, Minami-Ise, Mie 516-0193, Japan
}

\begin{abstract}
Juveniles of the Pacific oyster Crassostrea gigas were reared on a monospecific microalgal diet in order to quantify their ${ }^{13} \mathrm{C}$ and ${ }^{15} \mathrm{~N}$ diet-tissue fractionations. The weights of these juveniles increased by up to 18 -fold within $33 \mathrm{~d}$. The juveniles reached isotopic equilibria with the diet, enabling calculations of fractionation values. The ${ }^{13} \mathrm{C}$ fractionation for tissues containing lipids ranked as $0.6 \%$ o (gill lamella) $>0.3 \%$ o (adductor muscle) $>-0.2 \%$ (mantle lobe) $>-0.9 \%$ o (whole soft body) $>-2.2 \%$ (midgut gland), while the ${ }^{15} \mathrm{~N}$ fractionation ranked as $8.7 \%$ (adductor muscle) $>6.5 \%$ (mantle lobe) $>5.4 \%$ (whole soft body) $>5.2 \%$ (gill lamella) $>2.3 \%$ o (midgut gland). Removal of lipids shifted the diet-equilibrated $\delta^{13} \mathrm{C}$ and $\delta^{15} \mathrm{~N}$ values in all tissues except the adductor muscle, with resultant increases in the ${ }^{13} \mathrm{C}$ and ${ }^{15} \mathrm{~N}$ fractionation values. The expected annual mean $\delta^{13} \mathrm{C}$ value for the diet of the oyster in the field is $-17.0 \%$, which is an intermediate value among the $\delta^{13} \mathrm{C}$ of coastal phytoplankton $(-20.2 \%)$, epilithon $(-20.0 \%)$, epipelon $(-14.8 \%)$, and seaweeds $(-14.9 \%)$, suggesting that the oyster feeds on a mixture of these micro- and macroalgae. The expected $\delta^{15} \mathrm{~N}$ diet value is $3.1 \%$, which is more depleted than values for micro- and macroalgae, suggesting that the ${ }^{15} \mathrm{~N}$ fractionation in the field is smaller than that obtained from the feeding experiment.
\end{abstract}

KEY WORDS: Stable isotopes · Trophic enrichment · Bivalve · Feeding experiment $\cdot$ Chaetoceros Crassostrea gigas

Resale or republication not permitted without written consent of the publisher

\section{INTRODUCTION}

The Pacific oyster Crassostrea gigas (Thunberg) is often dominant in intertidal and shallow subtidal reefs in many temperate regions and constitutes an important component in estuarine ecosystems. C. gigas is also of great economic importance as a species for oyster culture. Several isotopic studies in Europe (e.g. Riera \& Richard 1996, Riera et al. 2002) and in Japan (e.g. Takai et al. 2002) have attempted to determine the food sources of $C$. gigas.

Diet-tissue fractionation values that have been used to estimate food sources are 0 to $1.0 \%$ for ${ }^{13} \mathrm{C}$ (DeNiro \& Epstein 1978) and 3 to $4 \%$ for ${ }^{15} \mathrm{~N}$ (DeNiro \& Epstein 1981, Minagawa \& Wada 1984). However, the actual degree of fractionation is quite variable, depending on the species, tissue analyzed, and the method of sample preparation (Gearing et al. 1984, Vander Zanden \& Rasmussen 2001, McCutchan et al. 2003, Yokoyama et al. 2005). The fractionation values of Crassostrea gigas are indispensable to determine what food sources contribute to the diet and the trophic level of this species in the food web. Stephenson et al. (1986) reported extremely high ${ }^{13} \mathrm{C}$ fractionation (approximately $6 \%$ ) for the European flat oyster Ostrea edulis; however, there is no information on the fractionation of $C$. gigas. The aim of this study was to determine the ${ }^{13} \mathrm{C}$ and ${ }^{15} \mathrm{~N}$ fractionation values for tissues of $C$. gigas containing lipids and with lipids removed, based on a laboratory feeding experiment and to examine the validity of the values by comparison to field data.

\section{MATERIALS AND METHODS}

Feeding experiment. Juveniles of Crassostrea gigas, which had been produced as seed oysters for aquaculture in coastal waters in Miyagi Prefecture, Japan, were used for the experiment. Juveniles attaching on both sides of 3 shells of the Japanese scallop Patino- 
pecten yessoensis (shell length $=12.9$ to $14.5 \mathrm{~cm}$ ) were reared for $33 \mathrm{~d}$ in an aquarium $(39 \times 24 \times 15 \mathrm{~cm})$ filled with $14 \mathrm{l}$ of seawater. The shell length and shell height of the juvenile C. gigas at the beginning of the experiment ranged from 3.6 to $14.0 \mathrm{~mm}$ and from 3.7 to $16.0 \mathrm{~mm}$, respectively. The seawater introduced into the laboratory through a sand filter was further filtered through a Whatman GF/C glass fiber filter. Water temperature was in the range of 15 to $17^{\circ} \mathrm{C}$. Salinity ranged from 33.2 to 34.0 . The culture water was aerated using an electric air pump and was exchanged every day. Fecal matter produced from the cultured oysters was cleaned at the time of the water exchange. A commercial feed liquid (Tasaki Shinju), which contained concentrated living cells of the single-celled diatom Chaetoceros neogracile (Shütt) van Landingham (= C. gracilis reported by Yokoyama et al. 2005; cell size $=5$ to $8 \mu \mathrm{m}$, cell density $=4.0 \times 10^{8} \mathrm{ml}^{-1}, \mathrm{C}: \mathrm{N}$ ratio $=6.0$ ), was used as the sole diet for the oyster. This diet was selected for the oyster feed, because (1) Chaetoceros is among the most common genera in coastal phytoplankton of Pacific coastal waters of Japan (Terazaki 1990), and is considered as an important food source in the field, (2) C. neogracile cells in the feed liquid are living but the metabolic activities are maintained at low levels, and (3) this diet has acquired a good reputation from producers of seedlings for shellfish aquaculture (Oniki 2003). Ten to $20 \mathrm{ml}$ of the feed liquid were added to the aquarium twice daily in order to supply sufficient food and to attain rapid growth. The culture room was under natural light conditions, where the light intensity was $\sim 2 \mu \mathrm{mol} \mathrm{m}{ }^{-2} \mathrm{~s}^{-1}$. Twenty-eight oysters were sampled at the beginning of the feeding experiment to obtain initial isotopic values. In total, 54 reared oysters were subsampled after $4,10,18,25,32$, and $33 \mathrm{~d}$. The growth ratio (GR), as defined below, was adopted as an index to represent growth during the rearing period; $\mathrm{GR}=W_{\mathrm{f}} / W_{\mathrm{i}}$, where $W_{\mathrm{f}}$ and $W_{\mathrm{i}}$ are the final and initial dry weights (dry wt) of the whole soft body (WSB), respectively. $W_{\mathrm{i}}$ was estimated from shell length and shell height that were measured at the beginning of the experiment, based on a non-linear equation, $y=$ $0.0011 x^{1.629}\left(\mathrm{r}^{2}=0.852, \mathrm{n}=25\right)$, where $y$ is the dry wt (mg) of the WSB and $x$ is the product of shell length (mm) and shell height (mm) (Fig. 1).

Field survey. Crassostrea gigas was collected from an intertidal rocky shore $\left(34^{\circ} 20.7^{\prime} \mathrm{N}, 136^{\circ} 40.9^{\prime} \mathrm{E}\right)$ in Gokasho Bay in order to identify food sources in the field using the fractionation values obtained by the feeding experiment. Five to 8 adult specimens were sampled monthly from March 2001 to March 2002.

Sample preparation and analysis of isotopic composition. The oysters sampled were kept overnight in sand-filtered running seawater to allow evacuation of

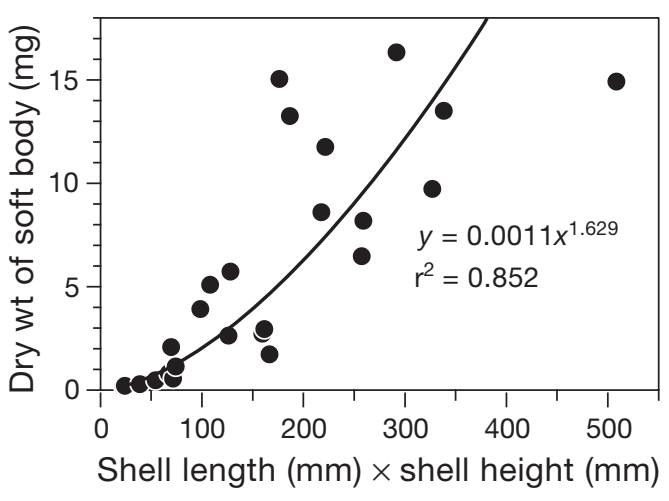

Fig. 1. Crassostrea gigas. Allometry of the Pacific oyster

the intestinal contents. Three of the 28 oysters sampled at the beginning of the experiment and 16 of the 54 oysters reared in the aquarium were dissected for the measurement of particular tissues (adductor muscle, mantle lobe, gill lamella, and midgut gland). The other oysters were used for the analysis of WSB. The collected samples were soaked in $1.2 \mathrm{~N} \mathrm{HCl}$ for 2 to $3 \mathrm{~min}$ to remove any carbonate debris, rinsed with distilled water, dried at $60^{\circ} \mathrm{C}$ for $1 \mathrm{~d}$, weighed to the nearest $1 \mu \mathrm{g}$, and ground to a powder, then divided into 2 subsamples for lipid removal and no treatment. For lipid removal, samples were soaked in a mixture of chloroform:methanol $(2: 1 \mathrm{v} / \mathrm{v})$ overnight, filtered on a Whatman GF/F glass fiber filter, rinsed with the chloroform: methanol solution, and subsequently dried again at $60^{\circ} \mathrm{C}$. The other subsample remained untreated. The diet, Chaetoceros neogracile cells, which were maintained alive in a dark refrigerator at $3^{\circ} \mathrm{C}$, were sampled 18 times during the experiment, and at each time 2 to 5 replicates were obtained. C. neogracile cells were collected on Whatman $\mathrm{GF} / \mathrm{F}$ filters and dried at $60^{\circ} \mathrm{C}$. WSBs of C. gigas collected from Gokasho Bay were dried at $60^{\circ} \mathrm{C}$ and ground to a powder for the analysis of their isotopic compositions.

The ${ }^{15} \mathrm{~N}$ and ${ }^{13} \mathrm{C}$ composition of the samples was determined using a mass spectrometer (MAT 252, Finnigan MAT) coupled on-line, via a Finnigan ConFlo II interface, with an elemental analyzer (EA 1110, ThermoQuest Italia). The results are expressed in the standard $\delta$ unit notation as $\delta X=\left[\left(R_{\text {samples }} / R_{\text {reference }}\right)-\right.$ 1] $\times 10^{3}$, where $X$ represents ${ }^{13} \mathrm{C}$ or ${ }^{15} \mathrm{~N}$, and $R$ is the ${ }^{13} \mathrm{C}:{ }^{12} \mathrm{C}$ or ${ }^{15} \mathrm{~N}:{ }^{14} \mathrm{~N}$ ratio for carbon and nitrogen, respectively. These values are reported relative to the Vienna Pee Dee Belemnite (PDB) standard for carbon and to atmospheric $\mathrm{N}_{2}$ for nitrogen.

Data analysis. Negative exponential equations of the form $y=\mathrm{ae}^{-\mathrm{bx}}+c$ were fitted to the experimental data, where $y$ is the $\delta^{13} \mathrm{C}$ or $\delta^{15} \mathrm{~N}$ value of the tissue in question, $x$ is the growth ratio, a and $b$ are constants, and 
$C$ is an asymptotic value (AV) of the tissue on the diet. The best-fit curves were optimized using the software KyPlot (Kyence). The diet-tissue fractionation (DTF) was calculated as DTF $=A V-D V$, where DV is the diet value.

Isotopic values of a hypothetical diet for the intertidal population in Gokasho Bay were estimated from the fractionation values obtained from the present experiment, and the calculated diet values were compared to those of the possible food sources in the study area, i.e. terrestrial organic matter, coastal phytoplankton, epipelon (benthic microalgae growing on sediments), epilithon (benthic microalgae growing attached to rock surfaces) and seaweeds. The monthly values of the former 4 sources, which were obtained at the same time as the sampling of the oysters, were reported by Yokoyama \& Ishihi $(2003,2006)$. We used data on seaweeds (mainly Sargassum spp.) that were obtained from Gokasho Bay during the period from April 1998 to July 1998 (Y. Ishihi \& H. Yokoyama, unpubl.).

\section{RESULTS AND DISCUSSION}

\section{Diet}

There was a significant negative relationship ( $\mathrm{p}<$ $0.001, \mathrm{r}^{2}=0.216, \mathrm{n}=58$ ) between the diet (Chaetoceros neogracile) $\delta^{13} \mathrm{C}$ and the days elapsed after first feeding (Fig. 2a). The difference between the initial and final $\delta^{13} \mathrm{C}$ values of the diet estimated from the regression line $(0.16 \%)$ was smaller than the SD $(0.35 \%$ o $)$ of $\delta^{13} \mathrm{C}$ values for the lipid-containing (LC) WSB showing $>7$-fold increase in weight when the isotopic compositions attained approximate equilibria with the oysters' diet (see 'Results and discussion-fractionation values'). Hence, we adopted a mean $\delta^{13} \mathrm{C}$ of the diet during the experimental period as representative of the diet $\delta^{13} \mathrm{C}$. On the other hand, the $\delta^{15} \mathrm{~N}$ values of the diet were constant throughout the experiment (Fig. 2b) ( $\mathrm{p}=0.49, \mathrm{r}^{2}=$ $0.009, \mathrm{n}=58)$. The overall mean $( \pm \mathrm{SD}) \delta^{13} \mathrm{C}$ and $\delta^{15} \mathrm{~N}$ values of the diet were $-10.9 \pm 0.1(\mathrm{n}=58)$ and -11.1 $\pm 0.1 \%$ o $(\mathrm{n}=58)$, respectively.

\section{Fractionation values}

The initial $\delta^{13} \mathrm{C}$ values ranged from $-17.6 \%$ for the LC midgut gland to $-15.6 \%$ for the LC and lipidremoved (LR) adductor muscle, while the initial $\delta^{15} \mathrm{~N}$ values ranged from $8.0 \%$ for the LC midgut gland to $11.3 \%$ for LR gill lamella. These isotopic values reflect the isotopic signatures of food particles in natural seawater. The oysters reared on the diet increased by 1.5 -

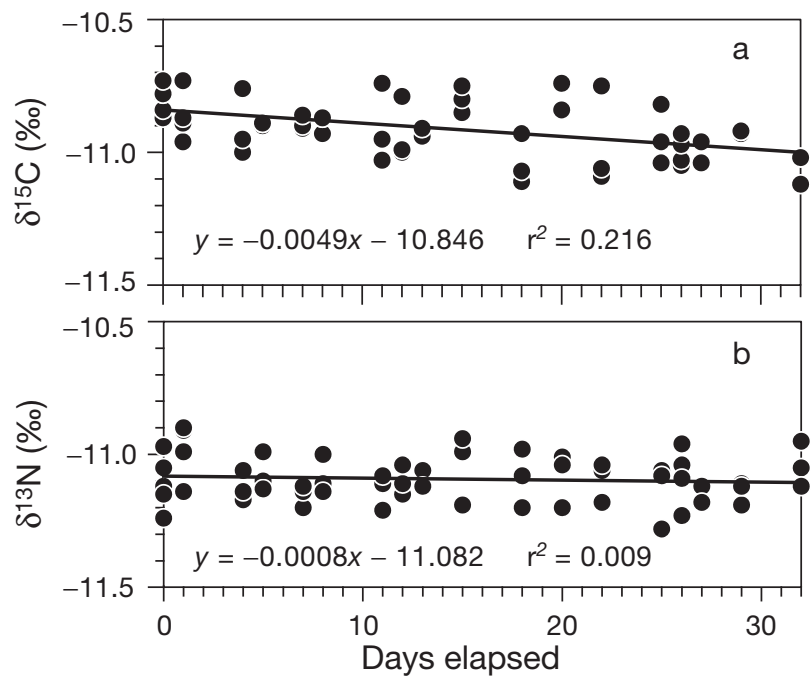

Fig. 2. Chaetoceros neogracile. (a) $\delta^{13} \mathrm{C}$ and (b) $\delta^{15} \mathrm{~N}$ for the diet of the oyster during the feeding experiment

to 18 -fold in weight during the 4 to $33 \mathrm{~d}$ of culture. The growth rates (mean $\pm \mathrm{SD}$ ) of the WSB (initial dry wt $=1.0 \pm 1.2 \mathrm{mg}$ ) and the shell heights (initial shell height $=8.3 \pm 2.8 \mathrm{~mm}$ ) were $0.16 \pm 0.12 \mathrm{mg}$ dry wt $\mathrm{d}^{-1}$ and $0.18 \pm 0.15 \mathrm{~mm} \mathrm{~d}^{-1}$, respectively. Considering that an intertidal juvenile population showed a mean shell growth rate of $0.15 \mathrm{~mm} \mathrm{~d}^{-1}$ (Hirata et al. 2006), the growth of the oysters in the laboratory is considered to be normal.

As the oysters grew, carbon and nitrogen of the tissues were replaced rapidly by those derived from the diet, giving best-fit curves as expressed by negative exponential equations (Fig. 3, Table 1). The significant asymptotic $\delta^{13} \mathrm{C}$ and $\delta^{15} \mathrm{~N}$ values of all LC and LR tissues (all $\mathrm{p}<0.001$ ) were attained approximately after a 7 -fold increase in weight. There were significant differences in the LC and LR $\delta^{13} \mathrm{C}$ and $\delta^{15} \mathrm{~N}$ among the different tissues of the oysters showing $>7$-fold increase (Kruskal-Wallis test, all $\mathrm{p}<0.05$ ).

The differences between the isotopic values of the diet and the asymptotic $\delta^{13} \mathrm{C}$ and $\delta^{15} \mathrm{~N}$ values for the oyster tissues are regarded as the diet-tissue fractionation (Fig. 3, Table 1). The asymptotic $\delta^{13} \mathrm{C}$ value of LC tissues ranged from $-13.1 \%$ in midgut gland to $-10.3 \%$ in gill lamella. The ${ }^{13} \mathrm{C}$ fractionation ranked as $0.6 \%$ (gill lamella) $>0.3 \%$ (adductor muscle) $>-0.2 \%$ (mantle lobe) $>-2.2 \%$ (midgut gland). The asymptotic $\delta^{15} \mathrm{~N}$ value of LC individual tissues ranged from $-8.8 \%$ in the midgut gland to $-2.4 \%$ in the adductor muscle. The ${ }^{15} \mathrm{~N}$ fractionation ranked as $8.7 \%$ (adductor muscle) $>6.5 \%$ o (mantle lobe) $>5.2 \%$ (gill lamella) $>2.3 \%$ (midgut gland). LC WSB showed ${ }^{13} \mathrm{C}$ and ${ }^{15} \mathrm{~N}$ fractionation values of -0.9 and $5.4 \%$, respectively, which are outside the range of the 
currently accepted ${ }^{13} \mathrm{C}$ and ${ }^{15} \mathrm{~N}$ fractionations (i.e. 0 to $1 \%$ and 3 to $4 \%$, respectively).

Removal of lipids varied the asymptotic $\delta^{13} \mathrm{C}$ values of all tissues. The magnitude of the shift depended on the tissue type. The midgut gland showed the largest increase $(+2.9 \%$ ), whereas a distinct shift was not found in the adductor muscle $(-0.2 \%)$. Considering that lipids possess lower $\delta^{13} \mathrm{C}$ values than other biochemical fractions due to enzymatic discrimination against ${ }^{13} \mathrm{C}$ during lipid biosynthesis (Park \& Epstein

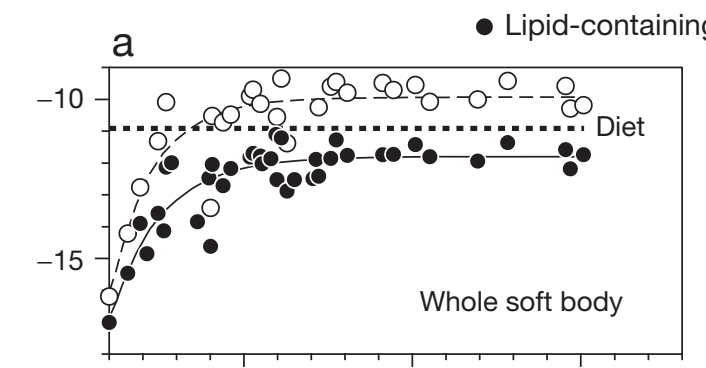

O Lipid-removed
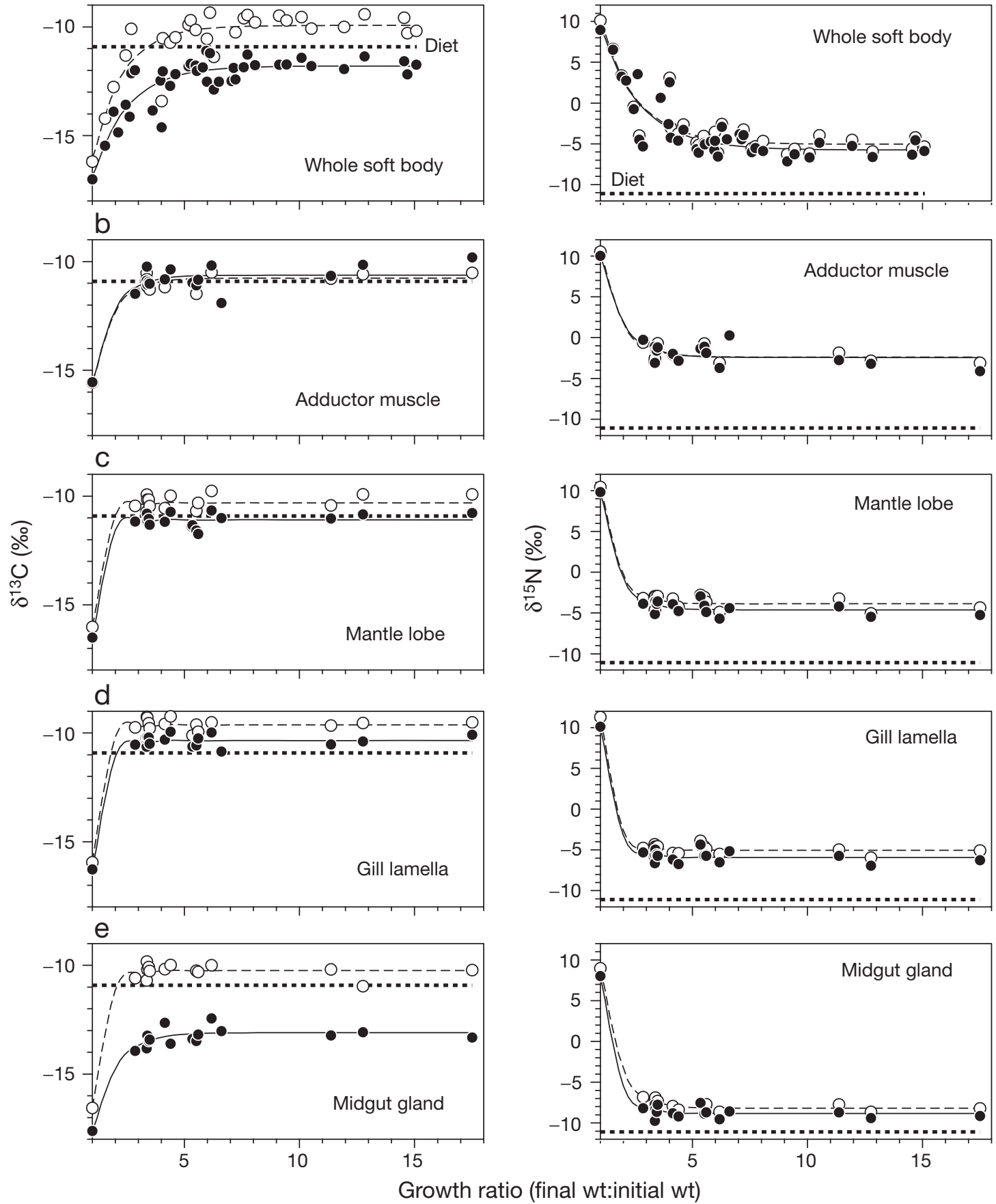

Fig. 3. Crassostrea gigas. $\delta^{13} \mathrm{C}$ (left column) and $\delta^{15} \mathrm{~N}$ (right column) of (a) whole soft body (WSB), (b) adductor muscle, (c) mantle lobe, (d) gill lamella, and (e) midgut gland as a function of the growth ratio. Dashed line indicates the mean $\delta^{13} \mathrm{C}$ or $\delta^{15} \mathrm{~N}$ value of the diet. Solid and broken lines are the best fit of the empirical data on the lipid-containing (LC) and lipid-removed (LR) tissues, respectively 
Table 1. Crassostrea gigas. Regression equations of the best-fit curves (see Fig. 3), coefficients of determination $\left(\mathrm{r}^{2}\right)$, sample sizes (n) of the feeding experiment, and diet-tissue fractionation (DTF) values

\begin{tabular}{|c|c|c|c|c|c|}
\hline$y$ & Tissue & Regression equation & $r^{2}$ & $\mathrm{n}$ & DTF \\
\hline \multicolumn{6}{|c|}{ Tissues containing lipids (LC) } \\
\hline$\delta^{13} \mathrm{C}$ & Whole soft body & $y=-9.8 \mathrm{e}^{-0.66 x}-11.8$ & 0.754 & 39 & -0.9 \\
\hline$\delta^{13} \mathrm{C}$ & Adductor muscle & $y=-15.5 e^{-1.15 x}-10.6$ & 0.852 & 17 & 0.3 \\
\hline$\delta^{13} \mathrm{C}$ & Mantle lobe & $y=-61.8 e^{-2.43 x}-11.1$ & 0.953 & 17 & -0.2 \\
\hline$\delta^{13} \mathrm{C}$ & Gill lamella & $y=-47.8 \mathrm{e}^{-2.09 x}-10.3$ & 0.972 & 17 & 0.6 \\
\hline$\delta^{13} \mathrm{C}$ & Midgut gland & $y=-12.6 \mathrm{e}^{-1.03 x}-13.1$ & 0.924 & 17 & -2.2 \\
\hline$\delta^{15} \mathrm{~N}$ & Whole soft body & $y=26.8 e^{-0.58 x}-5.7$ & 0.780 & 39 & 5.4 \\
\hline$\delta^{15} \mathrm{~N}$ & Adductor muscle & $y=36.6 \mathrm{e}^{-1.08 x}-2.4$ & 0.881 & 17 & 8.7 \\
\hline$\delta^{15} \mathrm{~N}$ & Mantle lobe & $y=53.9 \mathrm{e}^{-1.32 x}-4.6$ & 0.961 & 17 & 6.5 \\
\hline$\delta^{15} \mathrm{~N}$ & Gill lamella & $y=93.8 \mathrm{e}^{-1.77 x}-5.9$ & 0.972 & 17 & 5.2 \\
\hline$\delta^{15} \mathrm{~N}$ & Midgut gland & $y=83.9 \mathrm{e}^{-1.61 x}-8.8$ & 0.979 & 17 & 2.3 \\
\hline \multicolumn{6}{|c|}{ Tissues with lipids removed (LR) } \\
\hline$\delta^{13} \mathrm{C}$ & Whole soft body & $y=-13.1 \mathrm{e}^{-0.76 x}-9.9$ & 0.781 & 28 & 1.0 \\
\hline$\delta^{13} \mathrm{C}$ & Adductor muscle & $y=-15.2 e^{-1.15 x}-10.8$ & 0.944 & 13 & 0.1 \\
\hline$\delta^{13} \mathrm{C}$ & Mantle lobe & $y=-56.3 e^{-2.29 x}-10.3$ & 0.927 & 16 & 0.6 \\
\hline$\delta^{13} \mathrm{C}$ & Gill lamella & $y=-73.8 e^{-2.46 x}-9.6$ & 0.969 & 16 & 1.3 \\
\hline$\delta^{13} \mathrm{C}$ & Midgut gland & $y=-44.6 \mathrm{e}^{-1.95 x}-10.2$ & 0.970 & 15 & 0.7 \\
\hline$\delta^{15} \mathrm{~N}$ & Whole soft body & $y=28.6 \mathrm{e}^{-0.64 x}-5.1$ & 0.829 & 28 & 6.0 \\
\hline$\delta^{15} \mathrm{~N}$ & Adductor muscle & $y=41.0 \mathrm{e}^{-1.15 x}-2.4$ & 0.945 & 13 & 8.7 \\
\hline$\delta^{15} \mathrm{~N}$ & Mantle lobe & $y=58.4 \mathrm{e}^{-1.41 x}-3.9$ & 0.961 & 16 & 7.2 \\
\hline$\delta^{15} \mathrm{~N}$ & Gill lamella & $y=108.9 e^{-1.90 x}-5.0$ & 0.983 & 16 & 6.1 \\
\hline$\delta^{15} \mathrm{~N}$ & Midgut gland & $y=62.5 e^{-1.29 x}-8.2$ & 0.992 & 15 & 2.9 \\
\hline
\end{tabular}

1961, DeNiro \& Epstein 1977), the observed variations among the tissues probably resulted from the differences in the lipid content. Removal of lipids also increased the asymptotic $\delta^{15} \mathrm{~N}$ values of all tissues except the adductor muscle, suggesting that ${ }^{15} \mathrm{~N}$ depleted compounds were leached out from the tissues. The shift in the $\delta^{15} \mathrm{~N}$ of the 3 different tissues ranged from 0.6 (midgut gland) to $0.9 \%$ (gill lamella). Lipid removal resulted in 1.9 and $0.6 \%$ increases in the asymptotic $\delta^{13} \mathrm{C}$ and $\delta^{15} \mathrm{~N}$ values for the whole soft body, giving the ${ }^{13} \mathrm{C}$ and ${ }^{15} \mathrm{~N}$ fractionation values of 1.0 and $6.0 \%$, respectively. The former is within the range of the currently accepted ${ }^{13} \mathrm{C}$ fractionation value; however, the latter markedly deviates from the range.

\section{Implications for dietary reconstruction}

Yokoyama et al. (2005) conducted feeding experiments on the filter-feeding estuarine bivalves Ruditapes philippinarum and Mactra veneriformis and showed that the isotopic fractionations for the LC WSB ( 0.6 and $0.9 \%$ or for ${ }^{13} \mathrm{C}, 3.4$ to $3.6 \%$ o for ${ }^{15} \mathrm{~N}$, respectively) are within the range of the currently accepted values. The present study, however, shows distinct fractionations $\left(-0.9 \%\right.$ or for ${ }^{13} \mathrm{C}$ and $5.4 \%$ for ${ }^{15} \mathrm{~N}$ ) for another filter-feeding bivalve, Crassostrea gigas, even though the same commercial feed of Chaetoceros neogracile cells was used. The observed variation in the ${ }^{13} \mathrm{C}$ fractionation between the 2 experiments may be due to the difference in the lipid content between the 3 species of bivalves. The ${ }^{13} \mathrm{C}$ fractionation for the LR WSB of the oyster was $1.0 \%$, which is close to $1.4 \%$ for the LR WSB of $R$. philippinarum (Yokoyama \& Ishihi 2006). On the other hand, there is a large difference in the ${ }^{15} \mathrm{~N}$ fractionation between the LR WSBs of C. gigas (6.0\%) and R. philippinarum (3.8\%, Yokoyama \& Ishihi 2006). The large ${ }^{15} \mathrm{~N}$ fractionation for $C$. gigas is considered to occur through nitrogen turnover and metabolic processes, which cause the lighter isotopes to be preferentially lost and the heavier ones to be retained (Owens 1987, Fantle et al. 1999).

Isotopic values of the hypothetical diet of the oyster that were calculated based on LC WSB collected from Gokasho Bay ranged from (mean \pm SD) $-18.1 \pm 0.3 \%$ to $-15.9 \pm 0.4 \%$ for $\delta^{13} \mathrm{C}$ and from $1.9 \pm 0.2 \%$ o to $4.0 \pm$ $0.2 \%$ for $\delta^{15} \mathrm{~N}$ (Fig. $4 \mathrm{a}$ ). The annual mean $\delta^{13} \mathrm{C}$ value of the diet was $-17.0 \%$, which was intermediate among those of coastal phytoplankton $(-20.2 \%)$, epilithon $(-20.0 \%)$, epipelon $(-14.8 \%)$, and seaweeds $(-14.9 \%)$, suggesting that the oyster feeds on a mixture of these micro- and macroalgae. Recently, Nadon \& Himmelman (2006) expressed their concern that enriched $\delta^{13} \mathrm{C}$ values that had been recorded widely for many benthic consumers ranging from nearshore to offshore waters might have led to an overestimate of the contribution of ${ }^{13} \mathrm{C}$-rich benthic algae. However, the adoption of the negative ${ }^{13} \mathrm{C}$ fractionation that was determined in the present experiment for the oyster still emphasizes the contribution of benthic algae. 

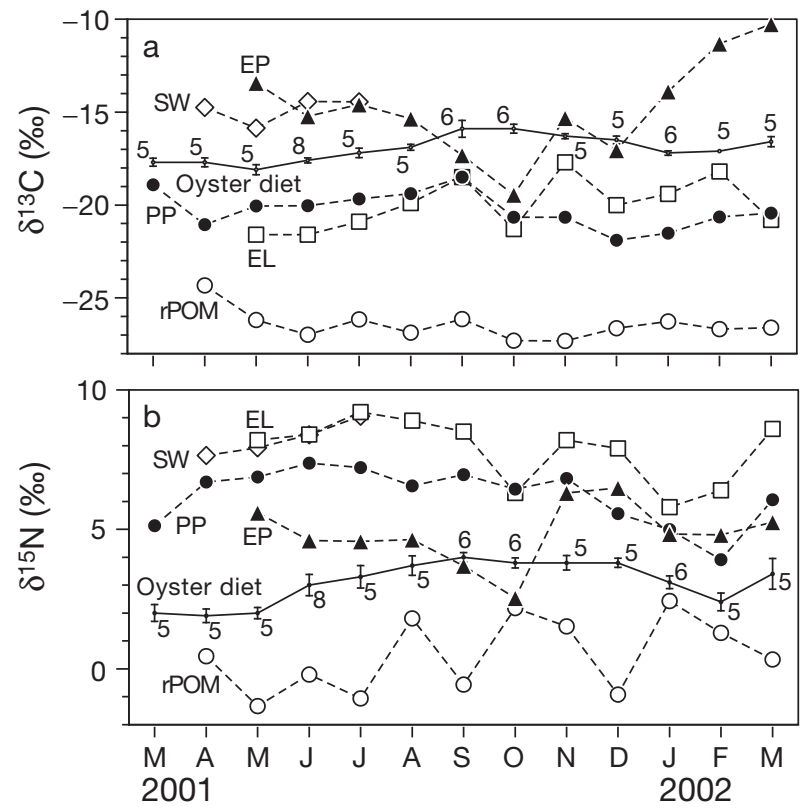

Fig. 4. Crassostrea gigas. (a) $\delta^{13} \mathrm{C}$ and (b) $\delta^{15} \mathrm{~N}$ for the hypothetical diet of oysters sampled from the rocky shore in Gokasho Bay (solid line) and their potential food sources (broken line). rPOM: terrestrial organic matter collected as riverine particulate organic matter, PP: coastal phytoplankton, EL: epilithic microalgae, EP: epipelic microalgae, SW: seaweeds. Error bars: $\pm \mathrm{SD}$, sample size (n) is given above or below each bar

The expected $\delta^{15} \mathrm{~N}$ value for the diet of the intertidal population in Gokasho Bay, which was estimated based on the diet-tissue fractionation values determined in this study, ranged from 1.9 to $4.0 \%$ (annual mean $=3.1 \%$ ), which was more depleted than those of coastal phytoplankton (6.0\%o), epilithon (7.9\%), epipelon $(4.8 \%$ ) , and seaweeds (8.3\%) (Fig. 4b). Terrestrial organic matter showed the most depleted $\delta^{15} \mathrm{~N}$ values $(0.5 \%$ ) in all end members; however, the large difference in the $\delta^{13} \mathrm{C}$ between the hypothetical diet and terrestrial organic matter $(-26.5 \%)$ indicates that terrestrial organic matter is not directly incorporated into growth of the oyster. The observed inconsistency suggests that the actual ${ }^{15} \mathrm{~N}$ diet-tissue fractionation in the field is smaller than that obtained from the present experiment.

It has been suggested that ${ }^{15} \mathrm{~N}$ fractionation is influenced by the quality of the diet. Fantle et al. (1999) demonstrated that diets showing high protein contents and low $\mathrm{C}: \mathrm{N}$ ratios decrease the ${ }^{15} \mathrm{~N}$ fractionation due to utilization of a substantial amount of nitrogen from the diet in the synthesis of tissue. They also suggested that starved animals must catabolize their own lipids and proteins, resulting in preferential excretion of light nitrogen and ${ }^{15} \mathrm{~N}$-enriched material remaining in animal tissues. Similar relationships between the quality of diet and the ${ }^{15} \mathrm{~N}$ fractionation have been reported for a locust (Webb et al. 1998) and a water flea (Adams \& Sterner 2000). On the other hand, McCutchan et al. (2003) suggested that the ${ }^{15} \mathrm{~N}$ fractionation is high when dietary nitrogen either exceeds or is well below requirements for optimal growth, and that the fractionation is low when dietary $\mathrm{N}$ is near the requirements. In the present study, large ${ }^{15} \mathrm{~N}$ fractionations were observed in the laboratory where the oysters were fed an excess of a single, N-rich diet (protein content = $0.28 \mathrm{~g} \mathrm{~g}^{-1}$ dry wt, Oniki 2003; C:N ratio $=6.0$ ) continuously throughout the day. In contrast, oysters in the field assimilate a mixed diet, which includes various groups of algae and small zooplankton (Kamiyama et al. 2005), and do not feed when the tide ebbs (average period of exposure to air at the sampling site $=8.4 \mathrm{~h}$ $\mathrm{d}^{-1}$ ). Such differences in food availability and in physiological conditions of the oyster between the field and the laboratory may lead to the differentiation in the fractionation values.

In conclusion, the fractionation in filter-feeding bivalves is species- and tissue-specific, and lipid removal possibly affects isotopic values of the tissues. For an objective dietary reconstruction, we must obtain information on the fractionation of the bivalve species under investigation. The diet-tissue fractionation should be determined by controlled feeding experiments, but our study demonstrates the importance of a field study to validate the determined values.

Acknowledgements. We thank M. Yamamoto for help during the experiment.

\section{LITERATURE CITED}

Adams TS, Sterner RW (2000) The effect of dietary nitrogen content on trophic level ${ }^{15} \mathrm{~N}$ enrichment. Limnol Oceanogr 45:601-607

DeNiro MJ, Epstein S (1977) Mechanism of carbon isotope fractionation associated with lipid synthesis. Science 197:261-263

DeNiro MJ, Epstein S (1978) Influence of diet on the distribution of carbon isotopes in animals. Geochim Cosmochim Acta 42:495-506

DeNiro MJ, Epstein S (1981) Influence of diet on the distribution of nitrogen isotopes in animals. Geochim Cosmochim Acta 45:341-351

Fantle MS, Dittel AI, Schwalm SM, Epifanio CE, Fogel ML (1999) A food web analysis of the juvenile blue crab, Callinectes sapidus, using stable isotopes in whole animals and individual amino acids. Oecologia 120:416-426

Gearing JN, Gearing PJ, Rudnick DT, Requejo AG, Hutchins MJ (1984) Isotopic variability of organic carbon in a phytoplankton-based, temperate estuary. Geochim Cosmochim Acta 48:1089-1098

Hirata Y, Wakano M, Takayama K, Akashige S (2006) Growth and survival of oyster spat under environment of hardening process in Hiroshima Bay. Bull Hiroshima Fish Mar Tech Cent 1:1-7 (in Japanese) 
Kamiyama T, Yamauchi H, Iwai T, Hanawa S, Matsuyama Y, Arima S, Kotani Y (2005) Comparison of environmental conditions in two representative oyster farming areas: Hiroshima Bay, western Japan, and Oginohama Bay (a branch of Ishinomaki Bay), northern Japan. Fish Sci 71:1295-1303

McCutchan JH Jr, Lewis WM Jr, Kendall C, McGrath CC (2003) Variation in trophic shift for stable isotope ratios of carbon, nitrogen, and sulfur. Oikos 102:378-390

- Minagawa M, Wada E (1984) Stepwise enrichment of ${ }^{15} \mathrm{~N}$ along food chains: further evidence and the relation between $\delta^{15} \mathrm{~N}$ and animal age. Geochim Cosmochim Acta 48:1135-1140

Nadon MO, Himmelman JH (2006) Stable isotopes in subtidal food webs: Have enriched carbon ratios in benthic consumers been misinterpreted? Limnol Oceanogr 51: $2828-2836$

Oniki H (2003) Production of concentrated pelagic diatoms. AquaNet 6:60-64 (in Japanese)

Owens NJP (1987) Natural variations in ${ }^{15} \mathrm{~N}$ in the marine environment. Adv Mar Biol 24:389-451

Park R, Epstein S (1961) Metabolic fractionation of $C^{13} \& C^{12}$ in plants. Plant Physiol 36:133-138

Riera P, Richard P (1996) Isotopic determination of food sources of Crassostrea gigas along a trophic gradient in the estuarine bay of Marennes-Oléron. Estuar Coast Shelf Sci 42:347-360

Riera P, Stal LJ, Nieuwenhuize J (2002) $\delta^{13} \mathrm{C}$ versus $\delta^{15} \mathrm{~N}$ of cooccurring molluscs within a community dominated by Crassostrea gigas and Crepidula fornicata (Oosterschelde, The Netherlands). Mar Ecol Prog Ser 240:291-295

Editorial responsibility: Otto Kinne, Oldendorf/Luhe, Germany
Stephenson RL, Tan FC, Mann KH (1986) Use of stable carbon isotope ratios to compare plant material and potential consumers in a seagrass bed and a kelp bed in Nova Scotia, Canada. Mar Ecol Prog Ser 30:1-7

Takai N, Mishima Y, Yorozu A, Hoshika A (2002) Carbon sources for demersal fish in the western Seto Inland Sea, Japan, examined by $\delta^{13} \mathrm{C}$ and $\delta^{15} \mathrm{~N}$ analyses. Limnol Oceanogr 47:730-741

Terazaki M (1990) Plankton in Japanese coastal waters. In: Coastal Oceanography Research Committee of The Oceanographic Society of Japan (ed) Coastal oceanography of the Japanese islands, Suppl Vol. Tokai University Press, Tokyo, p 265-281 (in Japanese)

Vander Zanden MJ, Rasmussen JB (2001) Variation in $\delta^{15} \mathrm{~N}$ and $\delta^{13} \mathrm{C}$ trophic fractionation: implications for aquatic food web studies. Limnol Oceanogr 46:2061-2066

Webb SC, Hedges REM, Simpson SJ (1998) Diet quality influences the $\delta^{13} \mathrm{C}$ and $\delta^{15} \mathrm{~N}$ of locusts and their biochemical components. J Exp Biol 201:2903-2911

Yokoyama H, Ishihi Y (2003) Feeding of the bivalve Theora lubrica on benthic microalgae: isotopic evidence. Mar Ecol Prog Ser 255:303-309

Yokoyama $\mathrm{H}$, Ishihi $\mathrm{Y}$ (2006) Variation in $\delta^{13} \mathrm{C}$ and $\delta^{15} \mathrm{~N}$ among different tissues of three estuarine bivalves: implications for dietary reconstruction. Plankton Benthos Res 1: 178-182

Yokoyama H, Tamaki A, Harada K, Shimoda K, Koyama K, Ishihi Y (2005) Variability of diet-tissue isotopic fractionation in estuarine macrobenthos. Mar Ecol Prog Ser 296: $115-128$

Submitted: May 22, 2007; Accepted: October 26, 2007 Proofs received from author(s): April 1, 2008 